\title{
Heterogeneous vertical structure of the bacterioplankton community in a non-stratified Antarctic lake
}

\author{
JUAN A. VILLAESCUSA ${ }^{1}$, EMILIO O. CASAMAYOR ${ }^{2}$, CARLOS ROCHERA $^{1}$, ANTONIO QUESADA $^{3}$, \\ LUIGI MICHAUD ${ }^{4}$ and ANTONIO CAMACHO ${ }^{1 *}$ \\ ${ }^{1}$ Departamento de Microbiología y Ecología, Edificio de Investigación “Jeroni Muñoz”, Campus de Burjassot, \\ Universitat de València, E-46100 Burjassot, Spain \\ ${ }^{2}$ Centro de Estudios Avanzados de Blanes - CEAB.CSIC - C/ d'accés a la Cala St Francesc, 14, E-17300 Blanes, Spain \\ ${ }^{3}$ Departamento de Biologia C/ Darwin, 2 Universidad Autónoma de Madrid, Ciudad Universitaria de Cantoblanco, \\ 28049 Madrid, Spain \\ ${ }^{4}$ Dipartamento di Biologia Animale ed Ecologia Marina, Università degli Studi di Messina - Piazza Pugliatti, \\ 1 - 98122 Messina, Italia \\ *corresponding author: antonio.camacho@uv.es
}

\begin{abstract}
Bacterial community composition during summer was analysed in surface and bottom waters of the oligotrophic shallow $(4.5 \mathrm{~m}$ ) Lake Limnopolar (Livingston Island, South Shetland Islands, Antarctica), using $16 \mathrm{~S}$ rRNA gene clone libraries and sequencing. Up to $61 \%$ of the $16 \mathrm{~S}$ rDNA sequences found were closely related to sequences retrieved from lakes, glaciers or polar systems. The distribution of these sequences was not homogeneous, with vertical differences found in both bacterial taxa composition and isolation source of the closest match from GenBank. In the surface sample $86 \%$ of the sequences were related to bacteria found in soils, seawater or gut microbiota, probably explained by waterborne transport from the catchment, by wind through sea sprays, or local bird activity. Conversely, in the deep samples, $95 \%$ of the sequences were closer to bacteria typically described for lakes, glaciers or polar systems. The presence of benthic mosses covering the bottom of the lake favours a more stable deep layer leading to the existence of this biological heterogeneity through the water column, although the lake does not show physical-chemical stratification in summer. This study illustrates a strong influence of external factors on the microbial ecology of this model Antarctic lake.
\end{abstract}

Received 7 August 2012, accepted 13 August 2012

Key words: bacteria, biological stratification, maritime Antarctic lakes, vertical heterogeneity, 16S rRNA gene

\section{Introduction}

Antarctic lakes located in the ice-free regions represent only the $2 \%$ of the total continental ice-free surface, and include both freshwater and saline systems. Most of these water bodies have experienced little or no anthropogenic impact and, therefore, still harbour pristine biotopes. In Antarctic lakes the combination of extreme environmental stressors (i.e. low temperature, low photosynthetically active radiation, nutrient limitation, extended periods of ice-covering, limited availability of liquid water, and short growing season) leads to simple truncated food webs with no fish and a limited presence of grazing and burrowing organisms (Michaud et al. 2012). Such systems can be considered as sensitive indicators of environmental changes because snow and ice cover variations markedly affect all ecological variables (Quayle et al. 2002, García-Jurado et al. 2011). These environments may also be considered analogous to those present prior to the evolution of metazoans, and they are generally dominated by organisms of the microbial loop, including bacteria, protozoa and phytoplankton (Laybourn-Parry 2002, 2009).

Studies on the microbial ecology of Antarctic ecosystems have focused on the structure and dynamics of microbial communities, both bacteria and protists, using traditional black-box approaches (Laybourn-Parry et al. 1991, 1995, Bell \& Laybourn-Parry 1999, McKnight et al. 2000, Duarte et al. 2005). However, during the last decade studies have focused on the application of molecular techniques based on direct amplification of 16S rRNA ribosomal gene sequences by using PCR and subsequent molecular sequencing or hybridization techniques such as FISH (Pearce \& Butler 2002, Pearce et al. 2003, Pearce 2003, 2005, Unrein et al. 2005, Laybourn-Parry \& Pearce 2007). These studies have been a major step forward in the characterization of the microbial communities in Antarctic systems.

Byers Peninsula is one of the largest ice-free areas of Maritime Antarctica. The area is characterized by the presence of a large number of water bodies, which support the development of important planktonic microbial communities during the summer (Toro et al. 2007, Villaescusa et al. 2010). Lake Limnopolar is one of the lakes located on Byers Peninsula (Livingston Island, South Shetland Islands, Antarctica), that has been selected as a model lake for many studies (Camacho 2006a, Toro et al. 2007), as it is characteristic of most features of inland lakes in this region of Antarctica. This lake has been the focus of study over the 


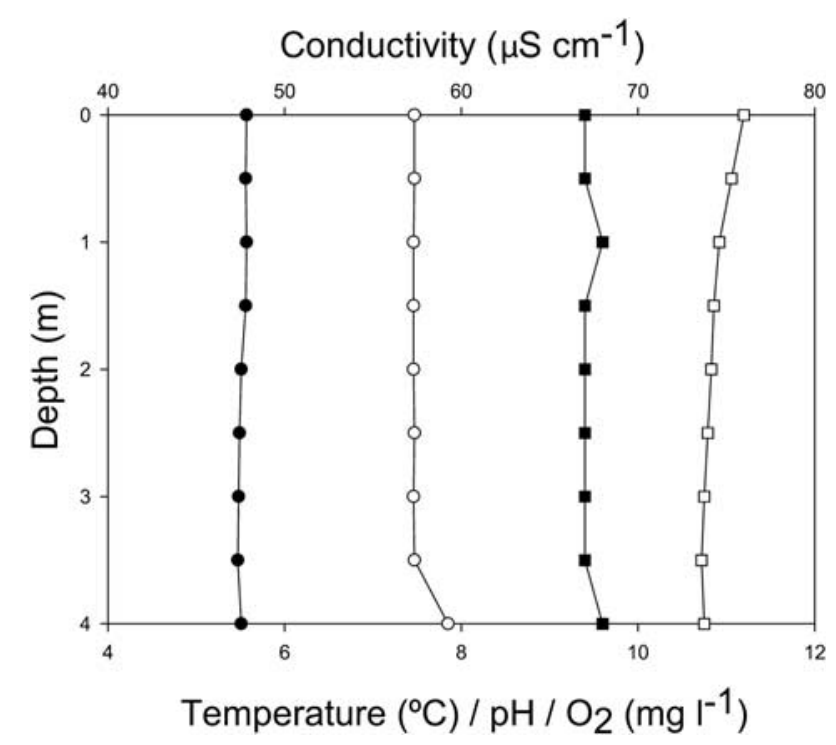

Fig. 1. Environmental variables measured in Lake Limnopolar at the sampling date, showing the homogeneity of the vertical structure of the lake. Variables shown are temperature $\left({ }^{\circ} \mathrm{C}\right)=$ black circles, $\mathrm{pH}=$ white circles, conductivity $\left(\mu \mathrm{S} \mathrm{cm}^{-1}\right)=$ black squares, and $\mathrm{O}_{2}\left(\mathrm{mg} \mathrm{l}^{-1}\right)=$ white squares.

last decade by the Spanish research team Limnopolar (www.uam.es/limnopolar). Part of this work has focused on investigating the ecological relationships implicit in the microbial food web, where the copepod Boeckella poppei Mrázek appears to be the main predator (Camacho 2006a, Toro et al. 2007), as in other Maritime Antarctic lakes (Butler et al. 2005). Metazooplankton may play an important role in Lake Limnopolar determining a top-down effect on the food web that extends to bacterioplankton (Camacho 2006a). A comparative study by genetic fingerprinting of the diversity of surface bacterioplankton in different lakes of Byers Peninsula was previously carried out (Villaescusa et al. 2010) showing a close relationship between physical and chemical features and the influence of lake's catchment processes on bacterial diversity. However, vertical heterogeneity within the bacterial assemblages was not previously investigated, as most of these lakes are shallow or cold monomictic, which results in thermal homogeneity and a non-stratified water column during summer. In such shallow oligotrophic systems, the physical and chemical variables remain relatively similar throughout the water column during the summer, causing a high degree of homogeneity in the system. However, the bottom of these lakes is often covered by large populations of the benthic moss Drepanocladus longifolius (Mitt.) Broth. ex Paris (Toro et al. 2007). These occurrences may generate stability in the bottom waters (Montecino et al. 1991, Imura et al. 2003), and thus may enhance vertical biological stratification. A previous study (Villaescusa et al. 2010) showed the influence of this
Table I. Environmental variables measured at the selected depths of Lake Limnopolar at the sampling date.

\begin{tabular}{lll}
\hline & \multicolumn{2}{c}{ Lake Limnopolar } \\
& $0.5 \mathrm{~m}$ & $4 \mathrm{~m}$ \\
\hline $\mathrm{NH}_{4}^{-}\left(\mathrm{mg} \mathrm{l}^{-1}\right)$ & 0.008 & 0.006 \\
$\mathrm{NO}_{3}^{-}\left(\mathrm{mg} \mathrm{l}^{-1}\right)$ & 0.01 & b.d.1. \\
$\mathrm{PO}_{4}^{-}\left(\mathrm{mg} \mathrm{l}^{-1}\right)$ & 0.006 & 0.008 \\
$\mathrm{Chl}^{-1}\left(\mu \mathrm{g} \mathrm{l}^{-1}\right)$ & 0.051 & 0.139 \\
Bacteria $\left(10^{6}\right.$ cell ml $\left.^{-1}\right)$ & 0.63 & 0.56 \\
Nanoflagelates $\left(\mathrm{ind} \mathrm{l}^{-1}\right)$ & b.d.l. & 801 \\
\hline
\end{tabular}

b.d.1. $=$ below detection limits.

benthic community on bacterioplankton diversity. The importance of stratification effects in lacustrine systems are well known, favouring the development of distinct microbial populations in the deep part of the lakes (Camacho 2006b). Even with the absence of a conspicuous physical-chemical stratification, the differences between surface and bottom waters due to the influences of catchment processes and the bottom coverage by mosses (also described in other Antarctic lakes, e.g. Sombre Lake in Signy Island, Pearce \& Butler 2002), can be an important source of bacterial diversity in these aquatic systems. In the present study we have explored the possible vertical heterogeneity of the planktonic microbial community of Lake Limnopolar by $16 \mathrm{~S}$ rRNA gene cloning and sequencing, analysing vertical changes in the bacterial community composition that could be explained by the influence of the moss carpet on the bottom waters and the influence of the catchment effects on surface waters.

\section{Material and methods}

\section{Study area and sampling}

Lake Limnopolar is on Byers Peninsula located between $62^{\circ} 34^{\prime} 35^{\prime \prime}-62^{\circ} 40^{\prime} 35^{\prime \prime} \mathrm{S}$ and 60 $54^{\prime} 14^{\prime \prime}-61^{\circ} 13^{\prime} 07^{\prime \prime} \mathrm{W}$. Lake Limnopolar is small (2.2 ha) and relatively shallow $(4.5 \mathrm{~m}$ maximum depth). It is a cold monomictic (showing only winter stratification) lake, which is ice-covered for most of the year. The ice-free period usually starts at the beginning of December, lasting approximately three months, but the ice-free time is closely related to winter dynamics and can be different each year (Rochera et al. 2010). The lake is oligotrophic due to low inorganic nutrients and organic

Table II. Comparison of bacterial diversities in the clone library for the two depths (alpha diversity) and the whole lake (Total, beta diversity) by means of the Chaol richness estimator and the reciprocal Simpson's dominance index. OTU $=$ operational taxonomic unit.

\begin{tabular}{lccr}
\hline & Lim $0.5 \mathrm{~m}$ & Lim $4 \mathrm{~m}$ & Total \\
\hline Number of clones & 76 & 101 & 177 \\
Number of OTUs & 24 & 21 & 42 \\
Chao1 estimator & 38 & 22 & 55 \\
Reciprocal Simpson index & 14 & 14 & 27 \\
Number of unique OTUs & 11 & 5 & 13 \\
\hline
\end{tabular}




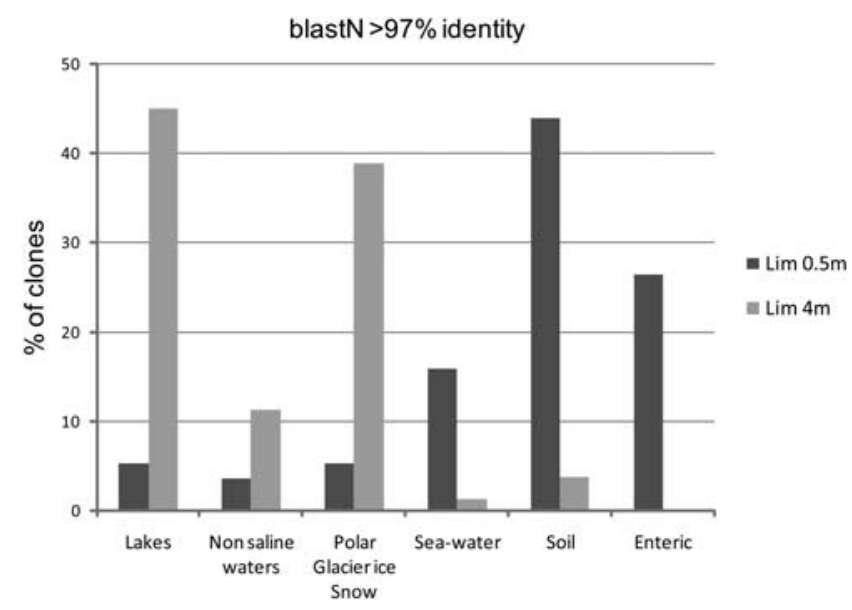

Fig. 2. Isolation sources of the closest BLAST match found in GenBank (search done September 2011) for each of the analysed samples. Only BLAST matches with more than 97\% identity were considered (species level).

matter inputs, which are primarily derived from the microbial mats within the lake basin (Fernández-Valiente et al. 2007). The lake food web has been described as having low complexity and is mainly dominated by microorganisms (Camacho 2006a).

The lake is $c .3 \mathrm{~km}$ from the ocean and the input from marine animals is limited to visiting birds, skua pairs and Antarctic terns, as demonstrated by repeated field observations. On 25 January 2007 sampling was done at Lake Limnopolar over the point of maximum depth. Vertical profiles of temperature, conductivity, $\mathrm{pH}$ and dissolved oxygen were obtained with a 6920 YSI multiparametric probe. Water samples from two depths $(0.5 \mathrm{~m}$ (surface waters, but not including neuston) and $4 \mathrm{~m}$ (bottom layer)) were collected with a hydrographic bottle (Uwitech), using 51 acid-washed plastic carboys. Physical, chemical and biological characteristics (electrical conductivity, temperature, $\mathrm{pH}$, dissolved oxygen, chlorophyll $a$ (chl $a$ ) concentrations, inorganic nitrogen and phosphorus, nanoflagellate abundance), were measured as described in Villaescusa et al. (2010).
Bacterioplankton abundance was measured using flow cytometry after dying the samples with SYBR Green-I.

\section{DNA extraction, 16S rRNA gene amplification, cloning and sequence analysis}

For the study of bacterial diversity in each sample a clone library was developed. Approximately an hour after the samples were collected, a volume of $300 \mathrm{ml}$ of water from the 51 plastic carboys from each depth was filtered through $0.2 \mu \mathrm{m}$ polycarbonate filters and preserved in DNA lysis buffer (40 mM EDTA, $50 \mathrm{mM}$ Tris $\mathrm{pH} 8.3,0.75$ sucrose) at $-20^{\circ} \mathrm{C}$. DNA was phenol extracted after enzymatic digestion (Dumestre et al. 2002).

Amplification of $16 \mathrm{~S}$ rRNA gene fragments was performed by using bacterial universal primers 27f (AGAGTTTGATC MTGGCTCAG) and 1492r (GGTTACCTTGTTACGACTT), and PCR conditions were established at $55^{\circ} \mathrm{C}$ annealing as previously described by Hervàs \& Casamayor (2009). Amplified DNA fragments were purified using a purification kit (Invitrogen ${ }^{\circledR}$ ), cloned (TOPO TA cloning ${ }^{\circledR}$ kit for sequencing, Invitrogen ${ }^{\circledR}$ ), and sent for one-reaction, onestrand sequencing (MacroGen, Korea). To minimize PCR limitations we were cautious in the number of PCR cycles run to avoid the 'plateau' phase and in using the same amount of template in each reaction. The samples that we compared were run in the same PCR run and analysed in exactly the same way. Any PCR bias should have been the same in all the samples and therefore, semiquantitative comparison between these samples would be still valid.

Next relatives of clones/isolates were determined by comparison to $16 \mathrm{~S}$ rRNA gene sequences in the NCBI GenBank and the EMBL databases using BLAST, and the "Seqmatch" and "Classifier" programs of the Ribosomal Database Project II (http://rdp.cme.msu.edu/, accessed July 2012).

All sequences with similarity $\geq 97 \%$ were considered to represent one phylogenetic group or phylotype (operational taxonomic unit (OTU)). Sequences were further aligned using the program Clustal W (Thompson et al. 1994) to the most similar orthologous sequences retrieved from database.
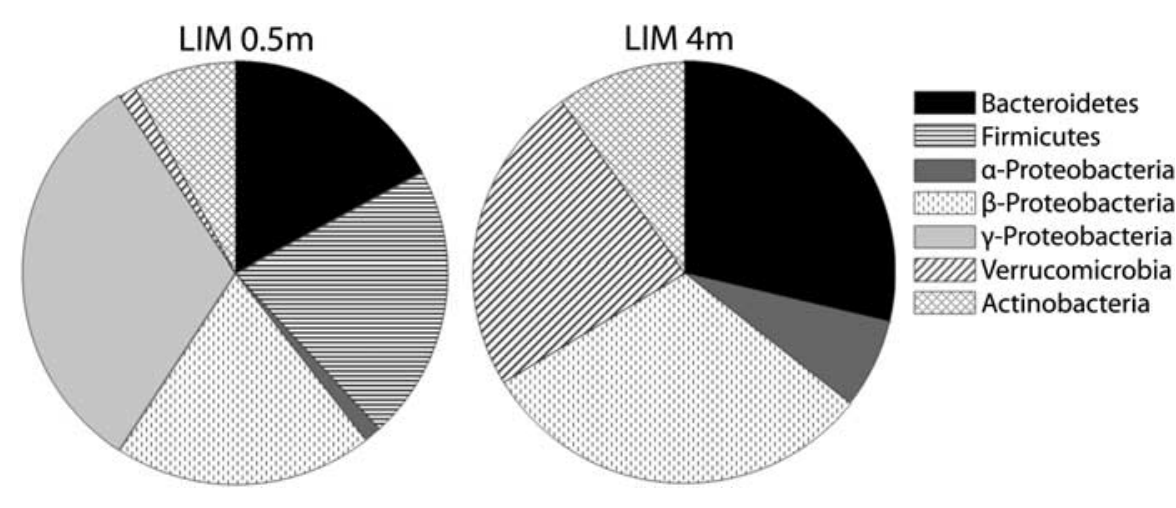

Fig. 3. Differences in the phylum (or Class) assignation among bacterial composition between lake surface $(0.5 \mathrm{~m})$ and lake bottom $(4 \mathrm{~m})$ in Lake Limnopolar. 


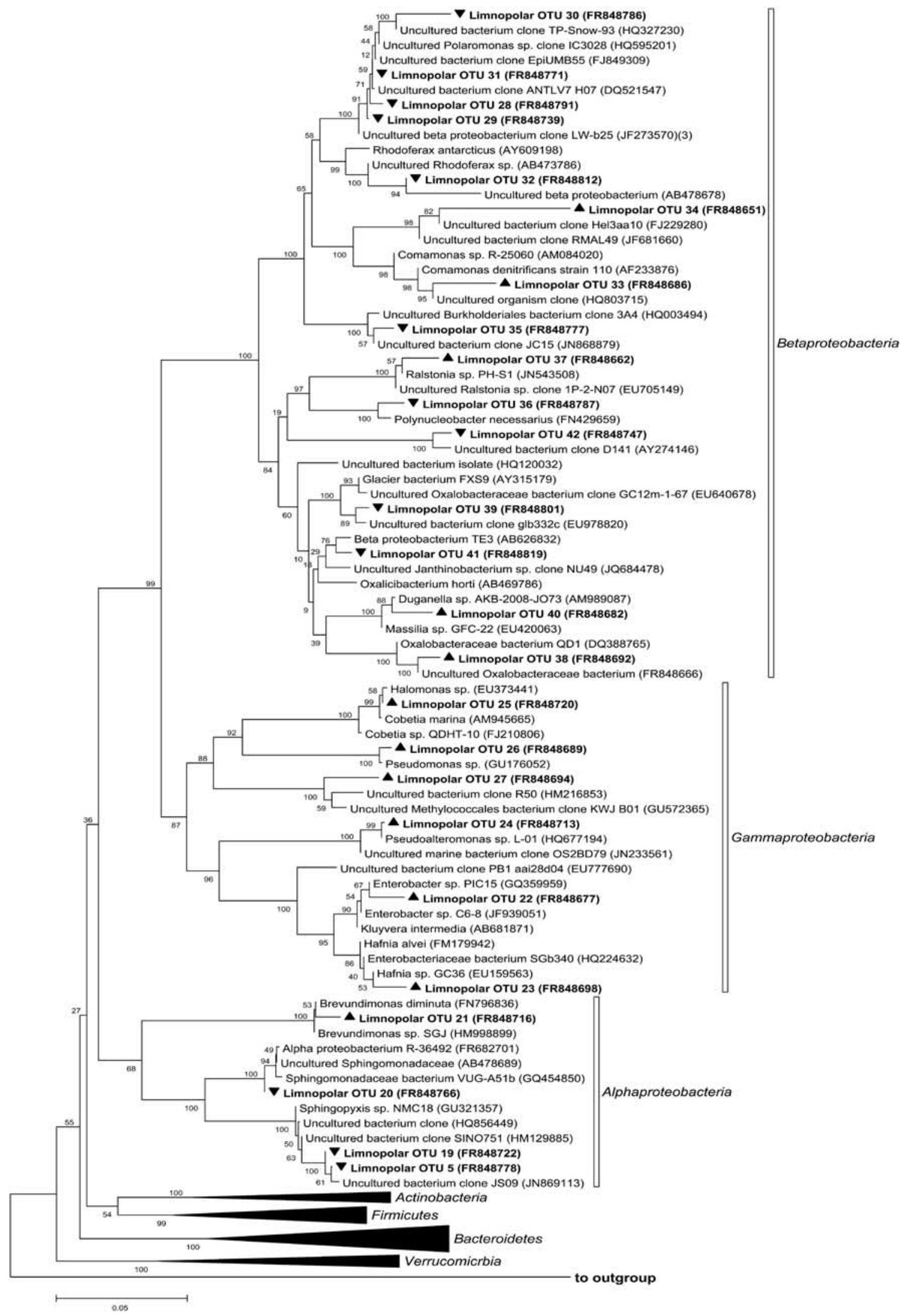

Fig. 4. Phylogenetic tree of the operational taxonomic units isolated from Lake Limnopolar. 


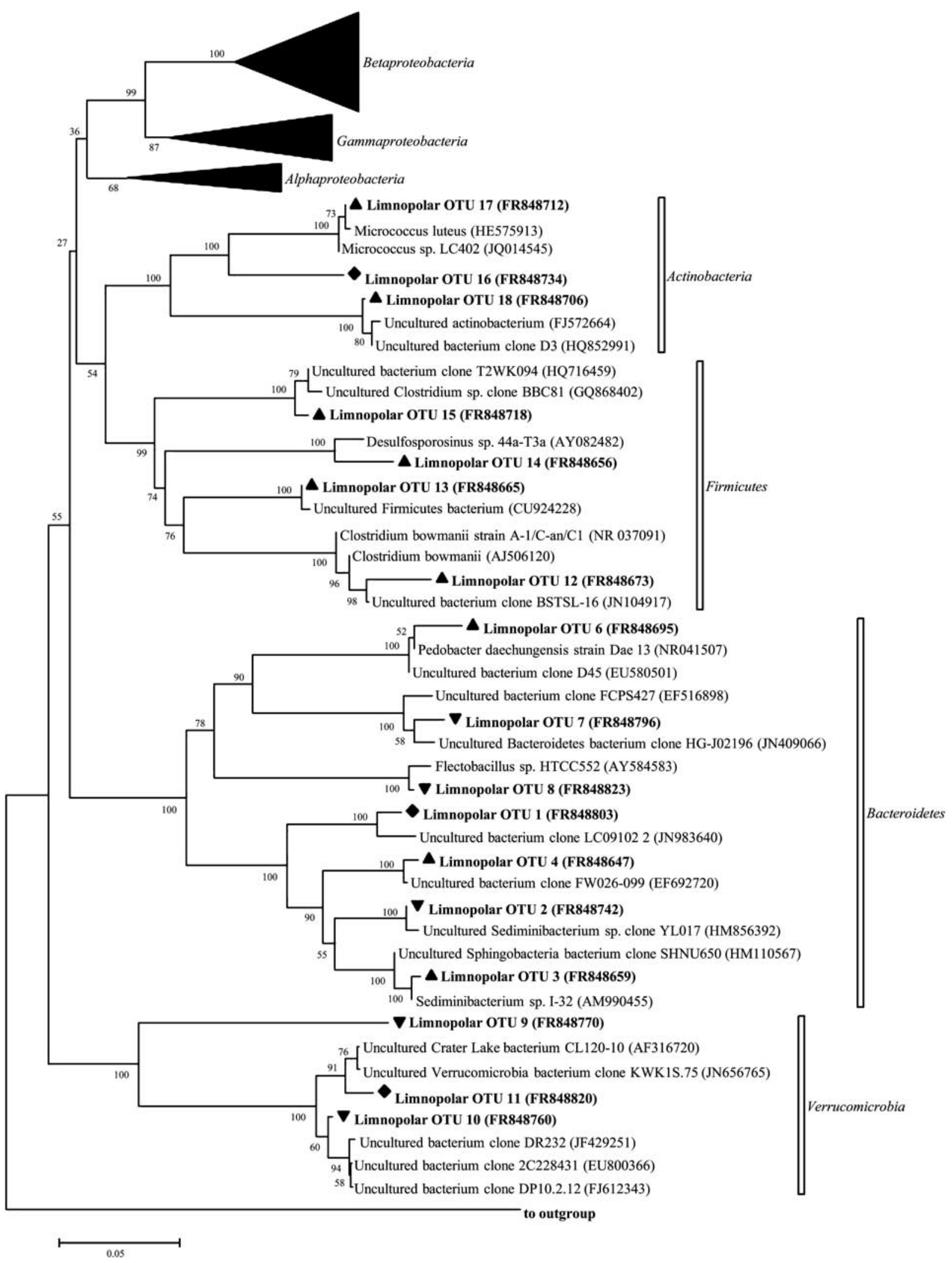

Fig. 4. Continued. 
Each alignment was checked manually, corrected and then analysed using the neighbour-joining method (Saitou \& Nei 1987) according to the model of Jukes-Cantor distances. A phylogenetic tree was constructed using the MEGA 5 (Molecular Evolutionary Genetics Analysis) software (Tamura et al. 2011). The robustness of the inferred trees was evaluated by 500 bootstrap re-samplings.

Coverage values were calculated in order to determine how efficiently the clone libraries described the complexity of the original bacterial community. The coverage (Good 1953) value is given as $\mathrm{C}=1-(\mathrm{n} 1 / \mathrm{N})$ where $\mathrm{n} 1$ is the number of clones which occurred only once in the library (singletons). The significance of differences among clone libraries was tested with Libshuff and the microbial composition significantly differed between samples (Libshuff test, $P<0.001$ ) (Singleton et al. 2001).

All 16S rRNA gene sequences were submitted to GenBank under the accession numbers FR 848645-FR 848824. Sequences grouped at $>97 \%$ identity were classified as different OTUs. In addition, we calculated the Chao1 index as a statistical estimator of richness, and the reciprocal Simpson's dominance index as an estimator of diversity for each single depth and for the whole lake (Xing et al. 2009).

\section{Results}

According to previous studies our sampling period is considered as the climax of the midsummer biological activity in the lake, occurring about one month after ice melt and water temperatures reaching the maximum annual values. Vertical profiles from Lake Limnopolar showed fairly homogeneous physical and chemical variables throughout the water column (Fig. 1); at this time temperature and specific conductivity were stable around $5.5^{\circ} \mathrm{C}$ and $68-69 \mu \mathrm{S} \mathrm{cm}^{-1}$, respectively. This resulted in almost no vertical density gradient and thus a complete mixing of the water column was expected. This is especially the case given the strong winds typical of this region. Among physical-chemical variables, the most remarkable difference is shown by the increase of c. 0.4 units of the $\mathrm{pH}$ at the depths where mosses extensively cover the lake bottom. Chemical and biological data (Table I) also showed an increase, such as that in chl $a$ concentration at the bottom of the lake. This increase in chl $a$ concentration was accompanied by a slight decrease in inorganic nitrogen concentrations (both ammonium and nitrate) and bacterioplankton abundance, similar to what was found in previous summers. Nanoflagellates were only detected in the deep part of the lake.

For the study of the bacterial community composition a total of 177 clones were processed and analysed (76 belonging to $0.5 \mathrm{~m}$ depth, $85 \%$ of coverage, and 101 to $4 \mathrm{~m}$ depth, $92.3 \%$ of coverage). The number of identified OTUs (Table II), 21-24 per depth sampled, was similar to that obtained in other limnetic systems when the same sampling effort was undertaken. The Chaol index and the Reciprocal Simpson's dominance index are shown in Table II.

Overall, the results show (Fig. 2) that c. $61 \%$ of identified clones (with at least $>97 \%$ identity) were related to sequences from temperate aquatic non-saline systems, polar systems or ice glaciers, while c. $20 \%$ of clones were related to soil bacteria. The rest of clones belonged to seawater bacteria and enterobacteria (gut microbiota). When comparing the surface with bottom water samples, a clear vertical segregation was observed. In surface waters up to $76 \%$ of the retrieved sequences were affiliated to bacteria found in soils, microbial mats, seawater, or even enteric bacteria, whereas in the deep samples almost all the sequences $(95 \%)$ were related with epicontinental water bodies even from non-polar regions and glaciers.

The comparison between sequences isolated from the surface and bottom waters showed differences in the relative abundance of each phylum (Fig. 3). The major differences appeared in the phylum Firmicutes, representing 21\% of the recovered sequences in the surface sample but these were not found in the bottom sample. Examining the branch of the phylogenetic tree (Fig. 4) for the phylum Firmicutes, these isolated sequences belong primarily to the order Clostridiales with a single genus, Clostridium. Our environmental sequences were closely related to cultured species such as C. psychrophilum, C. frigoris or C. lacusfryxellense. These sequences are closely related ( $>99 \%$ identity) to Antarctic psychrophilic bacteria isolated from microbial mats.

Representative sequences of Verrucomicrobia and Bacteroidetes phyla were relatively more abundant at the bottom of the lake, and this is especially true for the former, although both groups also were observed in the surface waters. Verrucomicrobia sequences were split into two different orders, Opitutales and Verrucomicrobiales, with some representatives closely related ( $>97 \%$ identity) to sequences from ultra oligotrophic lakes such as Crater Lake, USA.

Bacteroidetes were grouped in three orders, Sphingobacteriales, Cytophagales and Flavobacteriales. The order Sphingobacteriales appeared in both, surface and bottom samples. Inside this order were a large amount of sequences of $>98 \%$ identified with Sediminibacterium sp. In contrast, in the bottom of the lake, this phylum was mainly dominated by Cytophagales and Flavobacteria, represented by Flavobacterium sp. and Flectobacillus sp. These sequences were related ( $>97 \%$ identity) with bacteria isolated from ultra oligotrophic lakes, high mountain glaciers and polar areas. Some of them were also found in Antarctic lakes and others matched with sequences of uncultured bacteria from Arctic glaciers.

Sequences within the Actinobacteria phylum were found throughout the water column of the lake. These sequences 
were closely related ( $>99 \%$ identity) to sequences of uncultured Micrococcus sp. commonly retrieved from oligotrophic lakes and Arctic glaciers.

The phylum Proteobacteria was the main group represented in the whole set of retrieved sequences. The relative contributions of Proteobacteria sequences as a whole in the surface and bottom lake samples were very similar. However, the classes Alpha-, Beta- and Gammaproteobacteria showed important qualitative and quantitative differences in the vertical profile (Fig. 3). Representatives of Alpha- and Betaproteobacteria were much more abundant in the bottom sample and the Gamma group was only found in the surface sample. Within this class the retrieved sequences were related to five orders: Enterobacteriales, Alteromonadales, Oceanospirillales, Methylococcales and Pseudomonadales. The Enterobacteriales sequences were closely related (>99\% identity) to Kluyvera sp. and Hafnia alvei, these two taxa are widely distributed in nature and are also found in the gut of some animals. Both microorganisms also have psychrotrophic characteristics. For the other orders, sequences were closely related ( $>99 \%$ identity) to marine bacteria of the genera Cobetia sp., Pseudomonas sp. and Pseudoalteromonas sp.

Alphaproteobacteria also showed differences in species composition between surface and bottom waters. The surface water sample had sequences related ( $>98 \%$ identity) to Brevundimonas sp., whereas in the bottom sequences were related ( $>97 \%$ identity) to Sphingomonas sp., this latter has been commonly isolated from temperate oligotrophic lakes.

Sequences from Betaproteobacteria were the most abundantly recovered after PCR-cloning in Lake Limnopolar. All of them were from a single order, Burkholderiales, represented by four families: Comamonadaceae, Burkholderiaceae, Methylophilales and Oxalobacteraceae. We noticed differences in the composition of families and species through the water column. In the surface sample, some sequences were related ( $>98 \%$ identity) to bacteria of the genera Ralstonia sp., Comamonas sp. and Massilia sp., whereas in the bottom of the lake, other sequences were related ( $>99 \%$ identity) to Polaromonas sp., a genus usually found in glaciers and Antarctic lakes. Sequences closely related ( $>98 \%$ identity) to Polynucleobacter sp., a cosmopolitan group commonly found in oligotrophic lakes also appeared.

\section{Discussion}

Lake Limnopolar displays a remarkable oligotrophic status (Toro et al. 2007, Villaescusa et al. 2010, and data herein) and can be used as a model lake for inland lakes of Maritime Antarctica. However, the inputs of organic matter from the microbial mats and surrounding vegetation (mainly composed by mosses and lichens) located within the lake drainage basin (Fernández-Valiente et al. 2007), and the presence of a benthic moss population
(Toro et al. 2007, Villaescusa et al. 2010) may be important in bacterioplankton development.

Bacterial beta diversity in the lake (estimated as a whole sample joining the 177 total isolated sequences, Table II) was similar to that observed in temperate lakes (Bosshard et al. 1999, Eiler \& Bertilsson 2004, Wu et al. 2007). However, when bacterial diversity was analysed separately for surface and lake bottom waters (alpha diversity, Table II) it much decreased compared to beta diversity. Separately, these lower alpha diversity values were more similar to those expected in cold-latitude oligotrophic lakes and high mountain lakes (Xing et al. 2009, Llorens-Marès et al. 2012). This difference between alpha and beta diversity is related to the existence of significant differences in terms of taxonomic composition between surface and bottom waters that are commonly attributed to spatial heterogeneity, and commonly is referred to as beta diversity. This point is of interest in further refining the species-area relationship found for microorganisms in lakes (Reche et al. 2005), with a higher increase of beta diversity than expected only from the habitat heterogeneity per unit area as discussed elsewhere (Barberán \& Casamayor 2011).

In Lake Limnopolar, it is not unreasonable to think of this vertical segregation of the bacterial assemblages as a biological stratification, even though a clear physical and chemical vertical gradient is not displayed. In this lake, biological interactions play a major role during the summer (Camacho 2006a), and this also seems to be true in determining the composition and distribution of the bacterioplankton community. The analysis of the retrieved sequences with $>97 \%$ identity (segregation criterion according to Tamames et al. 2010), and the origin of the closest matches found in GenBank, demonstrate the importance of the catchment inflow (soil bacteria), birds (enteric bacteria from birds faeces), and sea spray (airborne bacteria) in explaining the taxonomic composition of the bacterial community in surface waters. Contrastingly, bacterioplankton composition of deep waters is much more similar to that commonly described for other cold freshwater environments. This appears to be the case even though no physical stability of the water column is displayed, meaning that a more stable environment could be provided by the dense carpet of mosses covering the bottom of the lake, which confers a higher resilience to this bacterioplankton community.

The data obtained for Lake Limnopolar are in agreement with the idea of the dominance of Proteobacteria in Antarctic lakes (Pearce \& Butler 2002, Pearce 2003, Pearce et al. 2003, Mosier et al. 2007) followed in abundance by the Bacteroidetes phylum. If we delve into the Proteobacteria group, most clones belong to Betaproteobacteria, followed by Gammaproteobacteria, whereas Alphaproteobacteria were less represented (Fig. 4). This pattern is commonly found in non-marine aquatic systems (Barberán \& Casamayor 2010). 
Anyway, the interpretation of quantitative data should be carefully considered because of the well-known PCR-cloning limitations, even though we were quite careful with the analytical procedures. With our procedures, any PCR bias should have been the same in all the samples and we therefore consider that semiquantitative comparison between these samples would be still valid, although we did not use quantitative data in absolute terms.

The presence of psychrotrophic enteric related bacteria, such as Kluyvera sp. and Hafnia alvei (Park et al. 2006), in the lake surface reflected the proximity of sea birds like skuas (Catharacta lonnbergi Mathews) and individual Antarctic terns (Sterna vittata Gmelin) in the Byers Peninsula region. The visits of these bird species to the lake has been confirmed and repeatedly reported. Also, the presence of halotolerant and halophilic bacteria (Cobetia sp., Pseudomonas sp. and Pseudoalteromonas sp.) typically isolated from seawater environments also support the influence of bird visits to the lake as well as the effects of sea spray.

The fact of a marked biological heterogeneity in the lake is also evident by the lack of Gammaproteobacteria in the deepest part of the lake (Fig. 3) and the significant changes in specific bacterial composition within Alpha- and Betaproteobacteria.

The occurrence of many sequences of Sediminibacterium sp. (Bacteroidetes) in the surface samples which have been previously associated with reservoir and river sediments (Qu \& Yuan 2008) is probably related to the important inflows of water entering the lake from the watershed during the summer. This is especially important during the snow melt processes that add runoff of sediments and bacteria from soil and lake basin vegetation, including microbial mats. This is also supported by the presence of species such as C. psychrophilum, C. frigoris or C. lacusfryxellense, included within the phylum Firmicutes, usually associated with microbial mats (Spring et al. 2003).

\section{Conclusions}

Our main conclusion is the vertical heterogeneity in the bacterial community structure in this shallow lake. This heterogeneity is governed by continuous allochthonous inputs into the surface waters making the bacterial community inhabiting this layer quite distinct from the deepest portion of the lake. These inputs are sensitive to catchment variations in physical-chemical and biological processes. On the other hand, the benthic population of mosses appears to be exerting a stability effect in the deep part of the lake allowing the existence of bacterial species more associated with oligotrophic aquatic polar systems. The increase of c. 0.4 units of the $\mathrm{pH}$ at the depths where mosses extensively cover the lake bottom (below $3.5 \mathrm{~m}$ depth) can be attributed to the photosynthetic activity of mosses, which consumes inorganic carbon (i.e. $\mathrm{CO}_{2}$ ) and increases $\mathrm{pH}$ and the carbonate equilibrium in these soft waters. Our results demonstrate that, although this lake is not thermally stratified, the benthic biological community, namely the moss coverage, also exerts an important role by creating mesohabitats that either hold or stabilize specific bacterial populations, thus allowing a major differentiation of the catchment-influenced surface waters and the benthic community-influenced bottom waters. Therefore, although it is commonly thought that a lake non-stratified from the physical and chemical point of view should provide a homogeneous distribution of the biological community, Lake Limnopolar illustrates a non physical and chemical stratified lake with an important bacterioplankton stratification, that perhaps could be a common characteristic of Maritime Antarctic lakes where mosses cover the benthos, especially during the summer.

\section{Acknowledgements}

This study was supported by the project CGL2005-06549C02-02/ANT from the Spanish Ministry of Education and Science to AC, which was co-financed by European FEDER funds, and CGL2005-06549-C02-01/ANT to AQ. Part of the molecular analyses were funded by project CGL2006-27884E/ANT to EOC. Support for travel costs was also obtained from grants CGL2007-29841-E and CTM2008-05205-E, given by the Spanish Ministry of Science and Innovation to AC. The authors are indebted to the colleagues of the LIMNOPOLAR research team for their support, as well as to the crew of the ship Las Palmas (Spanish Navy) and the Marine Technology Unit (UTM-CSIC) for logistic support. We also thank Prof Berry Lyons for his editing of the manuscript, as well as to two anonymous reviewers for their suggestions to improve the manuscript. We also acknowledge the Central Service for the Support to Experimental Research (SCSIE) from the University of Valencia for their assistance with some of the analyses. This article was published thanks to the financial support given by the Ministerio de Ciencia e Innovación (Spain) with the grant ref. CTM2011-12973-E.

\section{References}

Barberán, A. \& Casamayor, E.O. 2010. Global phylogenetic community structure and beta-diversity patterns of surface bacterioplankton metacommunities. Aquatic Microbial Ecology, 59, 1-10.

Barberán, A. \& Casamayor, E.O. 2011. Euxinic freshwater hypolimnia promote bacterial endemicity in continental areas. Microbial Ecology, 61, 465-472.

Bell, E.M. \& Laybourn-Parry, J. 1999. Annual plankton dynamics in an Antarctic saline lake. Freshwater Biology, 41, 507-519.

Bosshard, P.P., SAntini, Y., Grüter, D., Stettler, R. \& BACHOFEN, R. 1999. Bacterial diversity and community composition in the chemocline of the meromictic alpine Lake Cadagno as revealed by $16 \mathrm{~S}$ rRNA gene analysis. FEMS Microbiology Ecology, 31, 173-182.

Butler, H., Atkinson, A. \& Gordon, M. 2005. Omnivory and predation impact of the calanoid copepod Boeckella popei in a Maritime Antarctic lake. Polar Biology, 28, 815-821. 
Самасно, A. 2006a. Planktonic microbial assemblages and the potential effects of metazooplankton predation on the food web of lakes from the Maritime Antarctica and sub-Antarctic islands. Reviews in Environmental Science and Biotechnology, 5, 167-185.

CAMACHO, A. 2006b. On the occurrence and ecological features of deep chlorophyll maxima (DCM) in Spanish stratified lakes. Limnetica, 25, 453-478.

Duarte, C.M., Agustí, S., Varqué, D., Agawin, N., Felipe, J., Casamayor, E.O. \& Gasol, J.M. 2005. Experimental test of bacteria-phytoplankton coupling in the Southern Ocean. Limnology and Oceanography, 50, $1844-1854$

Dumestre, J.F., Casamayor, E.O., Massana, R. \& Pedrós-Alió, C. 2002. Changes in bacterial and archaeal assemblages in an equatorial river induced by the water eutrophication of Petit Saut dam reservoir (French Guiana). Aquatic Microbial Ecology, 26, 209-221.

Eiler, A. \& Bertilsson, S. 2004. Composition of freshwater bacterial communities associated with cyanobacterial blooms in four Swedish lakes. Environmental Microbiology, 6, 1228-1243.

Fernández-Valiente, E., Camacho, A., Rochera, C., Rico, E., Vincent, W.F. \& QuesadA, A. 2007. Community structure and physiological characterization of microbial mats in Byers Peninsula, Livingston Island (South Shetland Islands, Antarctica). FEMS Microbiology Ecology, 59, 377-385.

García-Jurado, F., Jiménez-Gómez, F. \& Guerrero, F. 2011. Effects of a dry period on the limnological characteristics of a Mediterranean high mountain lake. Limnetica, 30, 5-16.

Good, I.J. 1953. The population frequencies of species and the estimation of the population parameters. Biometrika, 40, 237-264.

Hervìs, A. \& CASAMAYOR, E.O. 2009. High similarity between bacterioneuston and airborne bacterial community compositions in a high mountain lake area. FEMS Microbiology Ecology, 67, 219-228.

Imura, S., Bando, T., Saito, S., Seto, K. \& Kanda, H. 2003. Benthic moss pillars in Antarctic lakes. Polar Biology, 22, 137-140.

LAYBourn-PARRY, J. 2002. Survival mechanisms in Antarctic lakes. Philosophical Transactions of the Royal Society, B357, 863-869.

Laybourn-Parry, J. 2009. No place too cold. Science, 324, 1521-1522.

Laybourn-Parry, J. \& Pearce, D. 2007. The biodiversity and ecology of Antarctic lakes: models for evolution. Philosophical Transactions of the Royal Society, B362, 2273-2289.

Laybourn-Parry, J., Bayliss, P. \& Ellis-Evans, J.C. 1995. The dynamics of heterotrophic nanoflagellates and bacterioplankton in a large ultra-oligotrophic Antarctic lake. Journal of Plankton Research, 17, $1834-1850$

Laybourn-Parry, J., Marchant, H.J. \& Brown, P.E. 1991. The plankton of a large freshwater Antarctic lake. Journal of Plankton Research, 13, $1137-1150$

Llorens-Marès, T., Auguet, J.C. \& Casamayor, E.O. 2012. Winter to spring changes in bacterial community composition in the slush layer of a high-mountain lake (Lake Redon, Pyrenees). Environmental Microbiology Reports, 4, 50-56.

McKnight, D., Howes, B.L., Taylor, C.D. \& Goehringer, D.D. 2000. Phytoplankton dynamics in a stably stratified Antarctic lake during winter darkness. Journal of Phycolology, 36, 852-861.

Michaud, L., Caruso, C., Mangano, S., Interdonato, F., Bruni, V. \& Lo GiUdice, A. 2012. Predominance of Flavobacterium, Pseudomonas and Polaromonas within the prokaryotic community of freshwater shallow lakes in the northern Victoria Land, East Antarctica. FEMS Microbial Ecology, 10.1111/j.1574-6941.2012.01394.x.

Montecino, V., Pizarro, G., Cabrera, S. \& Contreras, M. 1991. Spatial and temporal photosynthetic compartments during summer in Antarctic Lake Kitiesh. Polar Biology, 11, 371-377.

Mosier, A.C., Murray, A.E. \& Frisen, C.H. 2007. Microbiota within the perennial ice cover of Lake Vida, Antarctica. FEMS Microbiology Ecology, 59, 274-288.
PARK, J.W., Yoo, J.S. \& RoH, D.H. 2006. Identification of novel psychrotolerant bacterial strain and production of beta-galactosidase. Misainmurhag Hoiji, 42, 40-46.

Pearce, D.A. 2003. Bacterioplankton community structure in a Maritime Antarctic oligotrophic lake during a period of holomixis, as determined by denaturing gradient gel electrophoresis (DGGE) and fluorescence in situ hybridization (FISH). Microbial Ecology, 46, 92-105.

Pearce, D.A. 2005. The structure and stability of the bacterioplankton community in Antarctic freshwater lakes, subject to extremely rapid environmental change. FEMS Microbiology Ecology, 53, 61-72.

Pearce, D.A. \& Butler, H.G. 2002. Short-term stability of the microbial community structure in a Maritime Antarctic lake. Polar Biology, 25, 479-487.

Pearce, D.A., Van der Gast, C.J., Lawley, B. \& Ellis-Evans, J.C. 2003. Bacterioplankton community diversity in a Maritime Antarctic lake, determined by culture-dependent and culture-independent techniques. FEMS Microbiogy Ecology, 45, 59-70.

Quayle, W.C., Peck, L.S., Peat, H., Ellis-Evans, J.C. \& Harrigan, P.R. 2002. Extreme responses to climate change in Antarctic lakes. Science, 295, 645 .

Qu, J.H. \& Yuan, H.L. 2008. Sediminibacterium salmoneum gen. nov., sp. nov., a member of the phylum Bacteroidetes isolated from sediment of a eutrophic reservoir. International Journal of Systematic and Evolutionary Microbiology, 58, 2191-2194.

Reche, I., Pulido-Villena, E., Morales-Baquero, R. \& Casamayor, E.O. 2005. Does ecosystem size determine aquatic bacterial richness? Ecology, 86, 1715-1722.

Rochera, C., Justel, A., Fernández-Valiente, E., Bañón, M., Rico, E., Toro, M., CAMAcho, A. \& QuesadA, A. 2010. Interannual meteorological variability and its effects on a lake from Maritime Antarctica. Polar Biology, 33, 1615-1628.

SAitou, N. \& NeI, M. 1987. The neighbor-joining method: a new method for reconstructing phylogenetic trees. Molecular Biology and Evolution, 4, 406-425.

Singleton, D.R., Furlong, M.A., Rathbun, S.L. \& Whitman, W.B. 2001. Quantitative comparisons of 16S rRNA gene sequence libraries from environmental samples. Applied and Environmental Microbiology, 67, 4374-4376.

Spring, S., Merkhoffer, B., Weiss, N., Kroppenstedt, R.M., Hippe, H. \& Stackebrandt, E. 2003. Characterization of novel psychrophilic clostridia from an Antarctic microbial mat: description of Clostridium frigoris sp. nov., Clostridium lacusfryxellense sp. nov., Clostridium bowmanii sp. nov. and Clostridium psychrophilum sp. nov. and reclassification of Clostridium laramiense as Clostridium estertheticum subsp. laramiense subsp. nov. International Journal of Systematic and Evolutionary Microbiology, 53, 1019-1029.

Tamames, J., Abellan, J.J., Pignatelli, M., Cаmacho, A. \& Moya, A. 2010. Environmental distribution of prokaryotic taxa. BMC Microbiology, 10.1186/1471-2180-10-85.

Tamura, K., Peterson, D., Peterson, N., Stecher, G., Nei, M. \& Kumar, S. 2011. MEGA5: molecular evolutionary genetics analysis using maximum likelihood, evolutionary distance, and maximum parsimony methods. Molecular Biology and Evolution, 28, 2731-2739

Thompson, J.D., Higgins, D.G. \& Gibson, T.J. 1994. ClUSTAL W: improving the sensitivity of progressive multiple sequence alignment through sequence weighting, position-specific gap penalties and weight matrix choice. Nucleic Acids Research, 22, 4673-4680.

Toro, M., Camacho, A., Rochera, C., Rico, E., Bañón, M., Fernández-Valiente, E., Marco, E., Justel, A., Avedaño, M.C., Ariosa, Y., Vincent, W.F. \& Quesada, A. 2007. Limnological characteristics of the freshwater ecosystems of Byers Peninsula, Livingston Island, in Maritime Antarctica. Polar Biology, 30, 635-649. 
Unrein, F., Izaguirre, I., Massana, R., Balagué, V. \& Gasol, J.M. 2005. Nanoplankton assemblages in Maritime Antarctic lakes: characterization and molecular fingerprinting comparison. Aquatic Microbial Ecology, 40, 269-282.

Villaescusa, J.A., Casamayor, E.O., Rochera, C., Velázquez, D., Chicote, A., Quesada, A. \& Camacho, A. 2010. A close link between bacterial community composition and environmental heterogeneity in Maritime Antarctic lakes. International Microbiology, 13, 67-77.
Wu, X., XI, W., Ye, W. \& YAng, H. 2007. Bacterial community composition of a shallow hypertrophic freshwater lake in China, revealed by $16 \mathrm{~S}$ rRNA gene sequences. FEMS Microbiology Ecology, 61, 85-96.

XING, P., HAHN, M.W. \& Wu, L.Q. 2009. Low taxon richness of bacterioplankton in high altitude lakes of the eastern Tibetan plateau, with a predominance of Bacteroidetes and Synechococcus spp. Applied and Environmental Microbiology, 75, 7017-7025. 